\title{
Protocol: a simple method for extracting next-generation sequencing quality genomic DNA from recalcitrant plant species
}

\author{
Adam Healey*, Agnelo Furtado, Tal Cooper and Robert J Henry
}

\begin{abstract}
Next-generation sequencing technologies rely on high quality DNA that is suitable for library preparation followed by sequencing. Some plant species store large amounts of phenolics and polysaccharides within their leaf tissue making genomic DNA extraction difficult. While many DNA extraction methods exist that contend with the presence of phenolics and polysaccharides, these methods rely on long incubations, multiple precipitations or commercially available kits to produce high molecular weight and contaminant-free DNA. In this protocol, we describe simple modifications to the established CTAB- based extraction method that allows for reliable isolation of high molecular weight genomic DNA from difficult to isolate plant species Corymbia (a eucalypt) and Coffea (coffee). The simplified protocol does not require multiple clean up steps or commercial based kits, and the isolated DNA passed stringent quality control standards for whole genome sequencing on Illumina HiSeq and TruSeq sequencing platforms.
\end{abstract}

Keywords: DNA extraction, Next-generation sequencing, CTAB, Corymbia, Coffea

\section{Introduction}

With the advent of next-generation sequencing (NGS) technologies, investigation into the genomes of important industrial plant species has never been easier or more economical. Traditionally, genome analysis has relied on relatively small amounts of DNA of moderate purity for the purpose of restriction enzyme fingerprinting or polymerase chain reaction (PCR) amplification. However, NGS technologies, such as the Illumina HiSeq and TruSeq platforms, allow for the investigation of the entire genome of plants and as such require the input of several micrograms of high quality DNA. In the context of NGS, high quality DNA is characterized as DNA that is predominantly high molecular weight with an A260/280 ratio between 1.8 and 2.0 and without contaminating substances, such as polysaccharides or phenolics [1,2], which impede or inhibit DNA library preparation for NGS. The quality and quantity requirements for plant DNA sequencing by NGS often confine extraction methods to using leaf material, which is

\footnotetext{
* Correspondence: adamhealey65@gmail.com

Queensland Alliance for Agriculture and Food Innovation, University of Queensland, Brisbane 4072, Australia
}

problematic due to the accumulation of high amounts of phenolics and polysaccharides within a variety of species [3,4]. Polysaccharides, due to their chemical properties, coprecipitate with genomic DNA, giving solutions a viscous, glue-like appearance [5] and are known to inhibit the NGS library preparation (Nock C, personal communication). Phenolics, such as terpenoids and tannins, undergo rapid oxidation upon their release from leaf tissue and irreversibly bind to the phosphate backbone of DNA, characterized by the browning of leaf material [6,7]. Both contaminants prevent the use of DNA for molecular biology purposes, such as PCR, restriction digests, or sequencing by inhibiting the action of polymerases or endonucleases $[8,9]$. Forest trees, such as Corymbia, and species belonging to the Coffea genus also accumulate these contaminants in their leaves, limiting the study of their genomes [10-12].

The majority of DNA extraction methods from plant leaf tissue are derived from the original hexadecyltrimethylammonium bromide (CTAB) based method, described by Doyle and Doyle in 1987 [13]. To contend with the problems associated with phenolics and polysaccharides, the protocol has been modified to include polyvinylpyrrolidone 
(PVP) and high salt solutions to isolate genomic DNA $[5,6,8,9,14,15]$. Unfortunately, these methods can be time consuming, either relying on long incubation steps, nuclei pre-extraction that increases handling time, or requiring multiple DNA washes and precipitations that decrease overall yield. For NGS library preparation, DNA from difficult-to-isolate plant species often require commercial kit based methods to supplement CTAB based extractions to generate genomic DNA of high enough quality to pass stringent conditions for library preparation $[4,16]$. Kit based extraction methods are intended to easily remove contaminants, but are often expensive, particularly when many samples are required for analysis. The problem of losing DNA through subsequent column washes or precipitations can be exacerbated when only small amount of leaf tissue is available for collection.

NGS quality control requirements are often very stringent and require preparation of DNA that is of high molecular weight with little evidence of band shearing, containing no evidence of contamination from protein, RNA or polysaccharides, and has a 260/280 nm absorbance ratio of approximately 1.8-2.0. A fast, simple, and reliable DNA extraction method that does not rely on long incubations, multiple DNA precipitations, or supplementation of commercial supplies or reagents to meet next-generation library preparation requirements will be invaluable to plant research. The method described below illustrates how the addition of PVP alone to an established CTAB based method does not necessarily translate to an effective DNA extraction protocol, and demonstrates how subtle manipulations to an extraction protocol can isolate high quality genomic DNA from recalcitrant plant species, free of contamination and suitable for NGS library preparation.

\section{Materials and methods Consumables}

$50 \mathrm{~mL}$ Falcon Tubes

RNAse A (Sigma Cat No. R6513)

Polyvinylpyrrolidone (PVP) (Sigma Cat No. PVP10) (not required)

Chloroform: Isoamyl alcohol 24:1 (Sigma Cat No. C0549)

Liquid nitrogen

$\beta$-mercaptoethanol (Sigma Cat No. 63689)

Trizma base (Sigma Cat No. 1503)

Ethylenediaminetetraacetic acid disodium salt dihydrate (EDTA) (Chem Supply Cat No. EA023)

Agarose (Amresco Cat No. 0710)

Sodium Chloride (NaCl) (Ajax Finechem Cat No. 1103414)

Hexadecyltrimethylammonium bromide (CTAB) (Sigma Cat No. 52365)

EcoRI (not required- used for quality assurance) (NEB Cat No. R0101S)
HindIII-HF (not required- used for quality assurance) (NEB Cat No. R3104S)

\section{Reagents}

Extraction Buffer: $100 \mathrm{mM}$ Tris- $\mathrm{HCl}$ (pH 7.5), $25 \mathrm{mM}$ EDTA, $1.5 \mathrm{M} \mathrm{NaCl}, 2 \%(\mathrm{w} / \mathrm{v}) \mathrm{CTAB}$, and $0.3 \%(\mathrm{v} / \mathrm{v})$ $\beta$-mercaptoethanol- added immediately before use RNAse A stock solution $(10 \mathrm{mg} / \mathrm{mL})$

$5 \mathrm{M} \mathrm{NaCl}$

$95 \%$ ethanol $(\mathrm{v} / \mathrm{v})$

$70 \%$ ethanol $(\mathrm{v} / \mathrm{v})$

TE Buffer: 10 mM Tris-HCl (pH 7.6), 0.1 mM EDTA

CutSmart Buffer (NEB Cat No. B7204S)

NEBuffer EcoRI (NEB Cat No. B0101S)

Equipment

Mortar and Pestle

Water Baths $\left(65^{\circ} \mathrm{C}\right.$ and $\left.37^{\circ} \mathrm{C}\right)$

Centrifuge (capable of spinning $50 \mathrm{~mL}$ centrifuge tubes at $5000 \times \mathrm{g})$

$-20^{\circ} \mathrm{C}$ Freezer

Gel electrophoresis system (e.g. Jordan Scientific JP-250)

NanoDrop UV/Vis Spectrophotometer (e.g. NanoDrop 8000, Thermo Scientific)

\section{Plant material and tissue collection}

Leaf tissue of Corymbia citriodora subsp. variegata, Corymbia henryi, Corymbia torelliana, and Corymbia citriodora subsp. citriodora was obtained from Queensland Department of Agriculture, Fisheries and Forestry in Gympie, Australia. Leaf tissue of Coffea brassii was obtained from the Australian Tropical Herbarium in Cairns, Australia. Leaf material after harvesting was transported on ice and stored at $-80^{\circ} \mathrm{C}$ until subjected to DNA extraction.

\section{Protocol}

Preparatory steps

Before grinding, pre-chill the mortar and pestle (to minimize frozen tissue thawing) and $95 \%$ ethanol solution at $-20^{\circ} \mathrm{C}$. Pre-heat water baths $\left(65^{\circ} \mathrm{C}\right.$ and $\left.37^{\circ} \mathrm{C}\right)$ before beginning the extraction. Once pre-heated, prepare $10 \mathrm{~mL}$ (per $1 \mathrm{~g}$ of leaf tissue) extraction buffer by adding $0.3 \%$ $(\mathrm{v} / \mathrm{v}) \beta$-mercaptoethanol in a $50 \mathrm{~mL}$ Falcon tube, and preheat in the $65^{\circ} \mathrm{C}$ water bath. PVP can also be added at this point, but is not required.

\section{Grinding and tissue disruption}

Using liquid nitrogen, grind $1 \mathrm{~g}$ of frozen leaf tissue into a fine powder. Place the powder into a new $50 \mathrm{~mL}$ Falcon tube and mix in the pre-heated extraction buffer. Put the sample into the $65^{\circ} \mathrm{C}$ water bath and mix by inversion every $10 \mathrm{~min}$ for $30 \mathrm{~min}-1 \mathrm{~h}$. After incubation, centrifuge the sample tube for $5 \mathrm{~min}$ at $5000 \times \mathrm{g}$ (to pellet and remove un-lysed leaf tissue) and decant the supernatant into a new $50 \mathrm{~mL}$ Falcon tube. 


\section{Protein Extraction and RNAse treatment}

Add 1 volume of chloroform: isoamyl alcohol to the solution and mix by inversion for $5 \mathrm{~min}$. Centrifuge the sample for $10 \mathrm{~min}$ at $5000 \times \mathrm{g}$ and pipette the upper aqueous phase into a new Falcon tube, taking care to avoid the aqueous/organic layer interface. Add $5 \mu \mathrm{L}$ of RNAse A $(10 \mathrm{mg} / \mathrm{mL})$ to the solution and incubate at $37^{\circ} \mathrm{C}$ for 15 min with periodic, gentle mixing. After incubation, add 1 volume of chloroform: isoamyl alcohol to the solution and mix by inversion for $5 \mathrm{~min}$. Centrifuge the solution for $10 \mathrm{~min}$ at $5000 \times \mathrm{g}$ and pipette the aqueous phase into a new Falcon tube, again taking care to avoid the organic layer.

\section{Precipitation}

Add $1 / 2$ volume of $5 \mathrm{M} \mathrm{NaCl}$ to the sample and mix gently by inversion. Then, add 3 volumes of cold $95 \%$ ethanol and mix gently by inversion. Place the tubes into a $-20^{\circ} \mathrm{C}$ freezer and incubate for $1 \mathrm{~h}$. NOTE: do not leave the sample at $-20^{\circ} \mathrm{C}$ for more than $1 \mathrm{~h}$ as both the $\mathrm{CTAB}$ and $\mathrm{NaCl}$ can precipitate from solution, preventing DNA isolation.

After incubation, centrifuge the Falcon tube for $10 \mathrm{~min}$ at $5000 \times \mathrm{g}$ to pellet the DNA. Carefully decant away the supernatant and wash the DNA pellet with $3 \mathrm{~mL}$ of $70 \%$ ethanol. Gently swirl the solution and centrifuge again for $10 \mathrm{~min}$ at $5000 \times \mathrm{g}$. Carefully decant the supernatant and air-dry DNA pellet for $15 \mathrm{~min}$ at room temperature. Once dried, suspend DNA in $200 \mu \mathrm{L}$ of TE buffer.

\section{DNA quality and quantity assessment}

Assess the quality of the extracted DNA using a NanoDrop $\mathrm{UV} / \mathrm{Vis}$ spectrophotometer and $0.7 \%(\mathrm{w} / \mathrm{v})$ agarose gel, looking for a single absorbance peak at $260 \mathrm{~nm}$, a $260 / 280$ absorbance ratio of 1.8-2.0, and no evidence of substantial band shearing or contamination (either RNA or polysaccharide).

\section{Comments}

Since the advent of the CTAB-based extraction method from plant leaves by Doyle and Doyle in 1987, many different iterations have been published, each with modifications to contend with the co-extractives of polyphenolics and polysaccharides present in the leaves of many plant species $[3,5-8,15]$. While having demonstrated their effectiveness for isolating DNA that is suitable for PCR amplification or restriction digests, all methods currently published in the literature require long incubations, and multiple precipitation steps and ethanol washes to produce RNA-free genomic DNA of high purity. As next-generation sequencing requires large amounts of high quality DNA, each additional precipitation and wash increases handling time and lowers overall yield. Commercial column based extraction kits, such as DNeasy (Qiagen, Australia) or Wizard (Promega, Australia), are effective for isolating contaminant free DNA from recalcitrant plant species, including eucalypts $[4,16]$. However, commercial kits can be expensive and carry the risk of losing DNA on the column, which in turn necessitates several extractions followed by pooling of DNA.

To test the modifications made to the extraction method (NGS protocol) against the well-established original CTAB method (used routinely in our laboratory to reliably extract high quality DNA from rice, sugarcane, barley and wheat for sequencing $[17,18])$, six grams of frozen Corymbia citriodora subsp. variegata leaf tissue was ground and aliquoted evenly into the extractions described below. The quality of DNA from each extraction was verified spectrophotometrically using a NanoDrop instrument and agarose gel electrophoresis. The NanoDrop absorbance profile is useful for detecting contamination such as protein, salts or polysaccharides, all of which can inhibit NGS library preparation. High quality DNA is characterized as having a $260 / 280 \mathrm{~nm}$ absorbance ratio of approximately 1.8 , with a single absorbance peak at $260 \mathrm{~nm}$. The spectrophotometric profile is also useful for detecting phenolic oxidation, as the aromatic structure will absorb at 230 and $270 \mathrm{~nm}$ [1]. If oxidation is suspected to have occurred, endonuclease digestion can be used to further assess DNA quality before library preparation as phenolics, which inhibit polymerases, also inhibit restriction enzymes $[8,9]$.

Visualization of DNA on an agarose gel provides evidence of band shearing and RNA and polysaccharide contamination. Mechanical disruption, such as vortexing, causes DNA strands to shred apart, indicated by a wide DNA band with poor resolution. NGS library submission requires intact, high molecular weight genomic DNA, so all solution mixing steps were done by gentle inversion. Gel electrophoresis is also beneficial for visualizing RNA and polysaccharides, both of which contaminate sequencing reactions. RNA is evident as a distinct banding pattern at various sizes throughout the gel, whereas polysaccharides will migrate quickly and conglomerate at the bottom of the gel as a non-distinct fluorescent structure. Yield was determined through relative band intensity approximation with 100 and $200 \mathrm{ng} \lambda$ DNA standards, as the NanoDrop concentration readings can inflate yield of genomic DNA.

\section{Traditional CTAB extraction method}

Using the original CTAB protocol, we were unsuccessful in isolating DNA from Corymbia leaves. During incubation at $65^{\circ} \mathrm{C}$, the extraction solution began darkening, eventually turning brown. Upon precipitation, despite the observation of a small, brown pellet, the agarose gel failed to reveal any DNA (Figure 1, lane 4). The UV/Vis spectrophotometer absorbance peaks at 220-230 nm and 270-280 nm (Figure 2A) are likely due to polysaccharide, phenol and aromatic co-extractives [1]. The browning of 


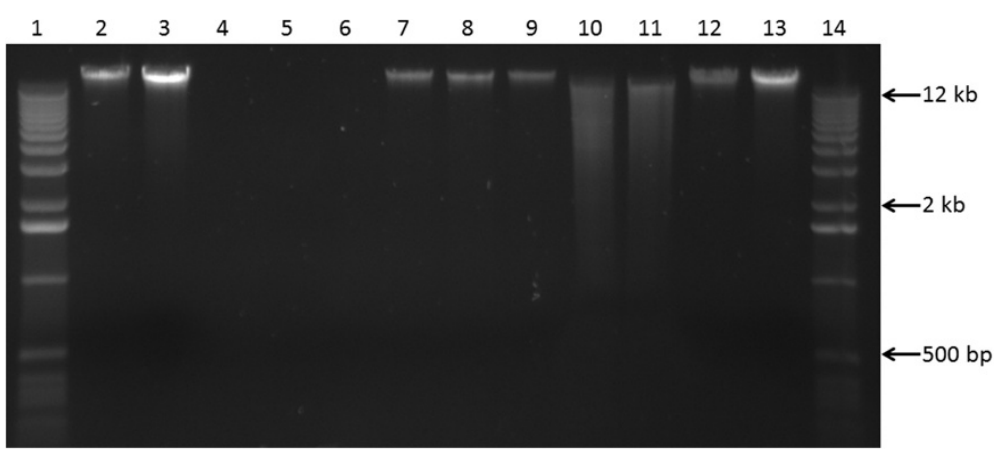

Figure 1 Genomic DNA preparation of Corymbia citriodora subsp. variegata resolved by electrophoresis. 1 kb DNA ladder (1, 14), 100 and $200 \mathrm{ng} \lambda$ DNA standards $(2,3$ and 12,13$)$ respectively. DNA extractions using the traditional CTAB-based method with no PVP (4), 1\% PVP (5), and 4\% PVP (6). DNA extractions using the NGS protocol with no PVP (7), 1\% PVP (8), and 4\% PVP (9). Endonuclease digestions of DNA extracted without PVP with EcoRI (10) and High-Fidelity HindIII (11). Results from six grams of leaf tissue finely ground using a mortar and pestle, then aliquoted $(1 \mathrm{~g})$ for each extraction. DNA was resolved by electrophoresis in a $0.7 \%$ agarose gel and visualized using SYBR Safe DNA gel stain. Percentages are represented as W/V. CTAB: hexadecyltrimethylammonium bromide; PVP: polyvinylpyrrolidone.

solution has been attributed to the oxidation of phenolic secondary metabolites in plant leaves $[4,6,19,20]$, a known problem with Corymbia [11,12] and Coffea [10].

The addition of PVP into CTAB based extractions to absorb phenolics, preventing their oxidation that renders DNA unusable for downstream application, has been used successfully for other recalcitrant plant species $[4,5,7,9]$, typically at a concentration of $1-2 \%(\mathrm{w} / \mathrm{v})$. The addition of $1 \%$ and $4 \%$ PVP to the traditional CTAB extraction method failed to isolate any useable DNA from Corymbia citriodora subsp. variegata. Again, the browning of solution occurred, and upon precipitation, a minute brown

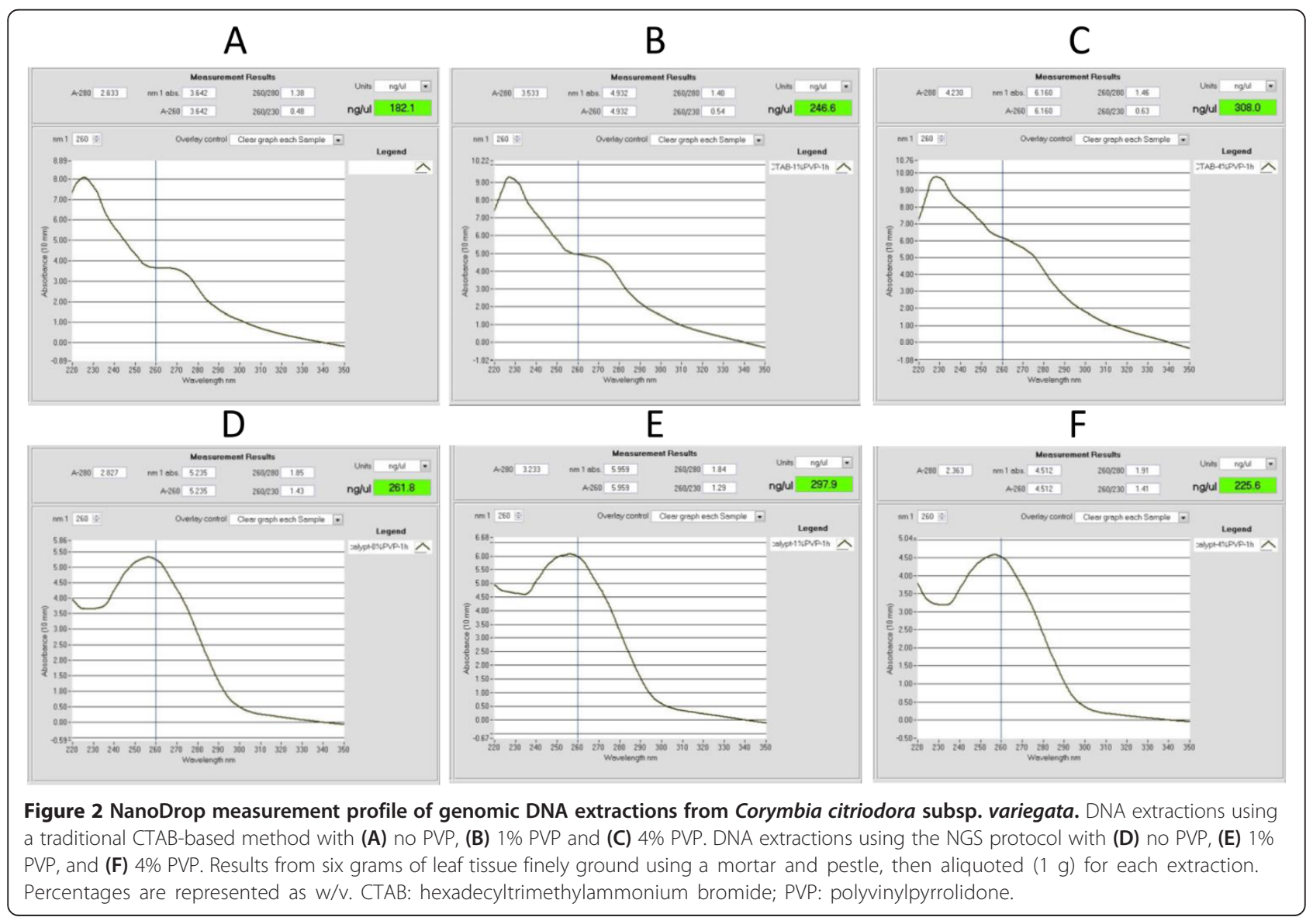


pellet was observed for each extraction. NanoDrop measurements revealed the persistence of the contamination absorbance peaks of 220-230 nm and 270-280 nm (Figure 2B-C). When resolved on a $0.7 \%$ agarose gel, no DNA was observed (Figure 1, lanes 5-6).

\section{NGS extraction protocol}

The NGS protocol allowed for the isolation of high quality DNA from Corymbia citriodora subsp. variegata. The NanoDrop spectrophotometer measurement profile showed a single absorbance peak at $260 \mathrm{~nm}$, and a 260/ 280 ratio of 1.85 (Figure 2D) Gel electrophoresis revealed a single, high molecular weight DNA band with little evidence of shearing and no RNA or polysaccharide contamination (Figure 1 lane 7). To further evaluate the quality of the extracted genomic DNA, approximately $1 \mu \mathrm{g}$ (per reaction) was digested overnight at $37^{\circ} \mathrm{C}$ with restriction enzymes EcoRI and High-Fidelity HindIII (New England BioLabs, Ipswich Massachusetts). Resolution of the digests on the agarose gel revealed efficient endonuclease activity of both enzymes (Figure 1 lanes 10 and 11, respectively).

The spectrophotometric profile and yield varied little when increasing amounts of PVP ( $1 \%$ and $4 \% \mathrm{w} / \mathrm{v})$ were added to the extraction buffer. Each DNA extraction had a 260/280 absorbance ratio of 1.84 and 1.91 respectively (Figure 2E-F), and high molecular weight DNA band with little shearing or contaminants (Figure 1 lanes $8-9$ ). Based on relative band intensity of the $2 \mu \mathrm{L}$ of sample resolved on the gel with the $100 \mathrm{ng} \lambda$ DNA standard, the method consistently yielded approximately $5 \mu \mathrm{g}$ of DNA per gram of leaf tissue. Although the A260/230 ratios (a secondary measure of DNA quality) [1] for the extractions were lower than expected $(1.41,1.29$, and 1.43 respectively), these results in combination with the endonuclease digestions suggested that PVP was not required to prevent phenolic oxidation, and the protocol was suitable for the isolation of DNA for whole genome NGS library preparation and sequencing. The modifications and considerations for the protocol are discussed below.

\section{Modifications}

The modifications to the previously cited methods were designed to simplify the protocol and maximize DNA yield by reducing the number of handling steps, DNA precipitations, and washes required, and eliminating the need for long incubations or supplementation with commercial based kits and reagents.

\section{Phenolic oxidation}

As shown (Figure 1 lanes 7-11 and Figure 2D-F), PVP was not required to prevent phenolic oxidation which renders DNA unsuitable for use. This is likely due to the presence of $\beta$-mercaptoethanol, a reducing agent [2], and the centrifugation step after $65^{\circ} \mathrm{C}$ incubation. The centrifugation and pelleting of un-lysed leaf material for removal was included to reduce the continued leeching of leaf phenolics into solution. Also, as un-lysed leaf tissue settles at the interface between the aqueous and organic phases during the first protein extraction step, its early removal increases the clarity between the two phases allowing easier pipetting of the aqueous portion. After centrifugation, chloroform: isoamyl alcohol was added as quickly as possible for further separate phenolics from the aqueous portion. If PVP has been added for phenolic absorption, the first protein extraction step will remove the majority, while the remainder is removed by the second extraction.

\section{RNAse treatment}

RNAse A treatment, a requirement for the isolation of high quality genomic DNA, is traditionally added after the DNA has been precipitated, washed and dissolved into a stabilizing buffer which necessitates additional steps to remove the enzyme and re-precipitate and wash the DNA. Each additional handling step and precipitation may produce DNA of higher quality, but decreases overall yield as typically, the simplest method for extraction will provide the most reliable result [21]. In this protocol, RNAse A was added between the two chloroform: isoamyl alcohol solvent extractions to allow for a single DNA precipitation step at the end of the protocol. As two washes using chloroform: isoamyl alcohol are required for high quality DNA extraction, the addition of the RNAse and the $15 \mathrm{mi}$ nute incubation at $37^{\circ} \mathrm{C}$ after the first solvent extraction efficiently digests RNA, while the second solvent extraction removes the enzyme. This eliminates the need for further treatments, precipitations and washes once the DNA was re-suspended in TE buffer during the final step of the procedure.

\section{Precipitation}

Included with the protocol was the addition of a high salt solution before DNA was precipitated with $95 \%$ cold ethanol. Polysaccharides have a similar solubility to DNA and co-precipitate in either isopropanol or ethanol, inhibiting downstream molecular application [4]. The addition of a high salt buffer increases their solubility in ethanol, allowing their removal once the DNA has been precipitated and pelleted [22]. During the $-20^{\circ} \mathrm{C}$ precipitation step, the $1 \mathrm{~h}$ incubation time should not be exceeded as $\mathrm{NaCl}$ and CTAB will eventually precipitate, preventing the DNA pellet from forming during centrifugation.

\section{NGS library submission, preparation and sequencing}

Based on the success of the method, the NGS protocol was applied to other samples of intended for NGS library preparation and sequencing. Due to limited amounts of leaf tissue available, 4\% PVP was included with the 
A

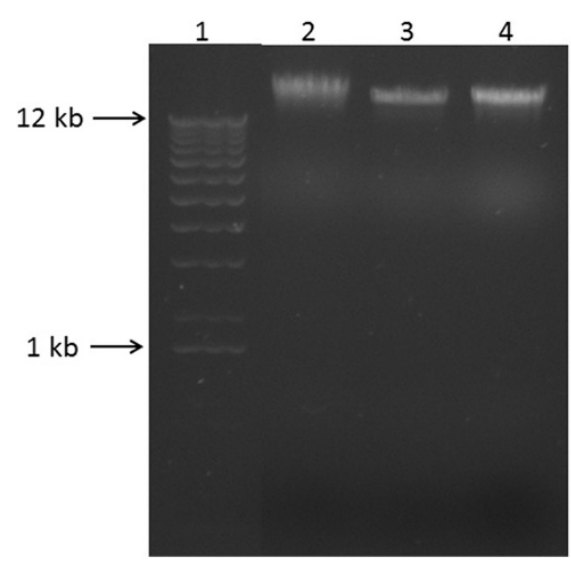

B

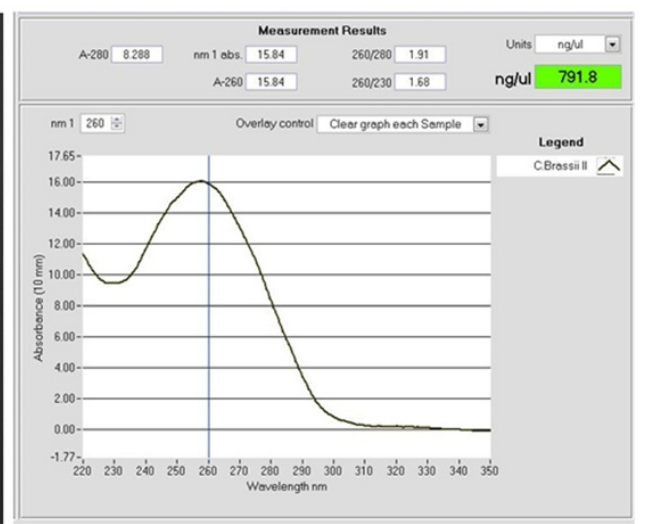

Figure 3 DNA quality and yield assessment for Coffea brassii genomic DNA using the NGS extraction protocol. A) Genomic DNA preparation of Coffea brassii resolved by electrophoresis. 1 kb DNA ladder (1), 100 ng and 200 ng $\lambda$ DNA standards respectively (3, 4), and DNA extraction using the modified NGS extraction protocol (2). DNA was separated by electrophoresis in a $0.7 \%$ agarose gel and visualized using SYBR Safe DNA gel stain. The gel image was cropped to exclude an unrelated sample. B) NanoDrop measurement profile of Coffea brassii leaf extracted genomic DNA using the modified NGS extraction protocol.

extraction for full confidence that no phenolic oxidation would occur. High quality DNA was extracted from Corymbia citriodora subsp. citriodora, Corymbia henryi, Corymbia citriodora subsp. variegata and Corymbia torelliana for NGS library preparation and sequencing. The Corymbia genomic DNA samples were submitted to the Joint Genome Institute (JGI) for library preparation and sequencing on the Illumina HiSeq 2500 platform and passed their quality control measures which require: high molecular weight genomic DNA free of polysaccharide, RNA and protein contamination, and a $260 / 280 \mathrm{~nm}$ absorbance ratio between 1.6 and 2.2.

The robustness of the NGS protocol was demonstrated with another recalcitrant plant genus, Coffea [10], to isolate high quality DNA from Coffea brassii for sequencing. As only 0.1 grams of $C$. brassii leaf material was available, the protocol was modified to use $5 \mathrm{~mL}$ of extraction buffer and $40 \mu \mathrm{L}$ of TE buffer to resuspend the DNA pellet. The DNA extraction was successful, the NanoDrop spectrophotometer profile showing a single $260 \mathrm{~nm}$ absorbance peak and a 260/280 nm absorbance ratio of 1.91 (Figure 3B). Resolution of $2 \mu \mathrm{L}$ of DNA by gel electrophoresis revealed high molecular weight DNA with little evidence of shearing and no observable contamination (Figure 3A). Based on relative band intensity with the $100 \mathrm{ng} \lambda$ DNA standard, approximately 1.5-2 $\mu \mathrm{g}$ of DNA was isolated, indicating a theoretical yield of $15-20 \mu \mathrm{g}$ of DNA per gram of leaf tissue. The C. brassii DNA sample was submitted to the Australian Genome Research Facility (AGRF) for library preparation and paired end sequencing on the Illumina TruSeq platform.

A summary of the DNA extractions for NGS library preparation and sequencing by JGI and AGRF is provided in Table 1.

\section{Sequencing quality}

As sequencing is influenced by the quality of DNA provided, raw Illumina reads from JGI and AGRF were assessed using read quality distributions, generated by CLC Bio Genomics WorkBench, software version 5.5.2 (CLC Bio, Denmark). Read quality distributions are based upon PHRED quality

Table 1 Summary of Corymbia and Coffea genomic DNA extractions and sequencing results from JGI and AGRF

\begin{tabular}{lllll}
\hline Species & $\begin{array}{l}\text { Absorbance } \\
\mathbf{2 6 0 / 2 8 0 ~} \mathbf{~ m}\end{array}$ & $\begin{array}{l}\text { Quantity of DNA } \\
\text { submitted }(\boldsymbol{\mu g})\end{array}$ & $\begin{array}{l}\text { NGS quality } \\
\text { control results }\end{array}$ & Number of sequencing reads \\
\hline Corymbia henryi & 1.78 & 19.1 & Pass (JGl) & $206,959,160(\mathrm{HiSeq})$ \\
Corymbia citriodora subsp. citriodora & 1.81 & 4.4 & Pass (JGl) & $169,513,988$ (HiSeq) \\
Corymbia citriodora subsp. variegata & 1.82 & 5.5 & Pass (JGl) & $234,021,522(\mathrm{HiSeq})$ \\
Corymbia torelliana & 1.93 & 6.3 & Pass (JGl) & $213,411,194$ (HiSeq) \\
Coffea brassii & 1.91 & 1.5 & Pass (AGRF) & $145,197,482$ (TruSeq) \\
\hline
\end{tabular}




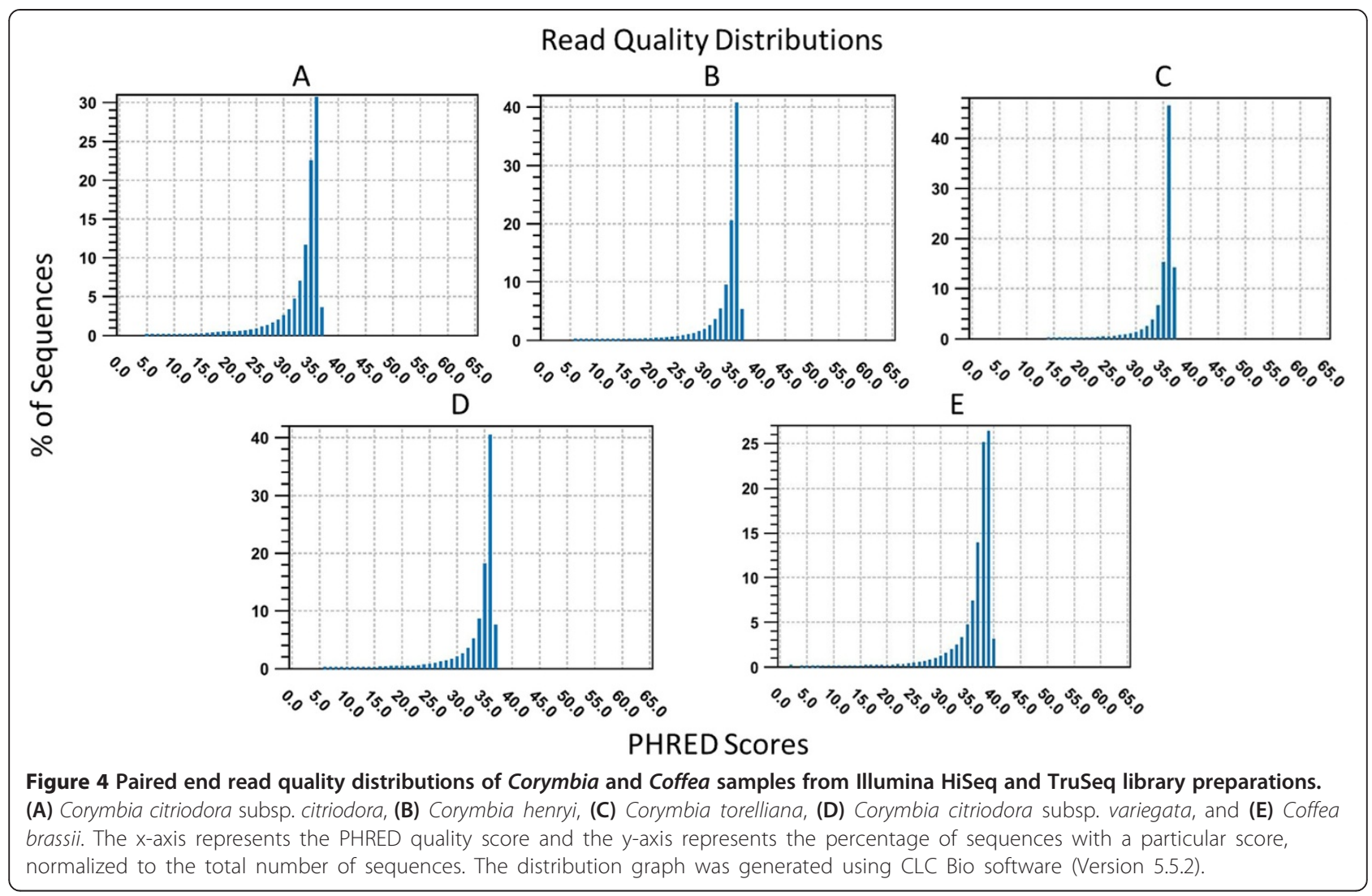

scores, which estimate the probability of error per base call [23]. The read quality distribution visualizes this data for the entire sequencing library, normalized to the total number or sequences.

Each Corymbia sequencing library (prepared by JGI, filtered above a PHRED score of 5) and the C. brassii sequencing library (prepared by AGRF) produced over 100 million reads per library, with a modal PHRED quality score of 36 and 39, respectively (Figure 4A-E). This represents a base call accuracy of approximately $99.999 \%$, providing high confidence in the quality of DNA submitted. Despite lower A260/230 ratios for the submitted Corymbia ( 1.4) and Coffea (1.68) samples, there were no observable differences between the library preparation and sequencing quality for the two species on either sequencing platform.

\section{Conclusion}

The described method, developed to improve genomic DNA extractions from leaf tissue of recalcitrant plant species, is a marked improvement over other methods as it does not require multiple clean up steps, precipitations, or commercial based kits or reagents. Using the protocol, high quality DNA was isolated from species of Corymbia and Coffea that passed stringent Illumina NGS library submission requirements, despite high amounts of high leaf phenolics and polysaccharides. The method was generated with the intent of using a single protocol for all plant species, regardless of the presence or absence of DNA co-extractive contaminants. With this robust protocol, whole-genome sequencing is possible from recalcitrant plant species using established DNA sequencing technologies for advanced bioinformatics investigations.

\section{Competing interests}

The authors declare they have no competing interests.

\section{Authors' contributions}

AH isolated genomic DNA from Corymbia and drafted the manuscript with sections written by AF. AH, AF, and RH developed and optimized the NGS protocol. TC extracted genomic DNA from C. brassii using the NGS protocol. All authors read and approved the final manuscript.

\section{Acknowledgements}

This work was supported by the University of Queensland and a postgraduate scholarship from the Queensland Alliance for Agriculture and Food Innovation. The authors would like to thank David Lee of the University of the Sunshine Coast and the Queensland Department of Agriculture, Fisheries and Forestry (QDAFF) for providing the Corymbia leaf material for extraction providing helpful comments for the manuscript, and Jason Lupoi of the Joint BioEnergy Institute for his comments. We thank Prof. Darren Crayn of Australian Tropical Herbarium for supplying the C. brassii leaves, Myrna Constantin for endonuclease digestions, and Joint Genome Institute and Australian Genome Research Facility for library preparation and sequencing of samples.

Received: 7 May 2014 Accepted: 23 June 2014

Published: 27 June 2014 
1. Thermo Scientific: $260 / 280$ and $260 / 230$ Ratios. In T009-Technical Bulletin. 2008:1-2.

2. Kasem S, Rice N, Henry R: DNA Extraction from Plant Tissue. In Plant Genotyping II: SNP Technology. Edited by Henry R, CAB International. 2008:219-271.

3. Križman M, Jakše J, Baričevič $D$, Javornik B, Prošek M: Robust CTAB-activated charcoal protocol for plant DNA extraction. Acta Agric Slov 2006, 87:427-433.

4. Tibbits JFG, Mcmanus $L$, Spokevicius AV, Bossinger G: A rapid method for tissue collection and high-throughput isolation of genomic DNA from mature trees. Plant Mol Biol Report 2006, 24:81-91.

5. Porebski S, Bailey LG, Baum BR: Modification of a CTAB DNA extraction protocol for plants containing high polysaccharide and polyphenol components. Plant Mol Biol Report 1997, 15:8-15.

6. Sahu SK, Thangaraj M, Kathiresan K: DNA extraction protocol for plants with high levels of secondary metabolites and polysaccharides without using liquid nitrogen and phenol. ISRN Mol Biol 2012, 2012:1-6.

7. Maliyakal JE: An efficient method for isolation of RNA and DNA from plants containing polyphenolics. Nucleic Acids Res 1992, 20:2381.

8. Kim CS, Lee $\mathrm{CH}$, Shin JS, Chung YS, Hyung NI: A simple and rapid method for isolation of high quality genomic DNA from fruit trees and conifers using PVP. Nucleic Acids Res 1997, 25:1085-1086.

9. Khanuja SPS, Shasany AK, Darokar MP, Kumar S: Rapid isolation of DNA from dry and fresh samples of plants producing large amounts of secondary metabolites and essential oils. Plant Mol Biol Report 1999, 17:1-7.

10. Labat M, Augur C, Rio B, Perraud-Gaimé I, Sayadi S: Biotechnological Potentialities Of Coffee And Similar With Olive, Two Models Of Agroindustrial Products Rich In Polyphenolic Compounds: A Review. In Coffee Biotechnology and Quality. Edited by Sera T, Soccol CR, Pandey A, Roussos S, Kluwer Academic Publishers. 2000:517-531.

11. Asante KS, Brophy JJ, Doran JC, Goldsack RJ, Hibbert DB, Larmour JS: A comparative study of the seedling leaf oils of the spotted gums: species of the Corymbia (Myrtaceae), section Politaria. Aust J Bot 2001, 49:55-66.

12. Brophy JJ, Forster PI, Goldsack RJ, Brynn Hibbert D: The essential oils of the yellow bloodwood eucalypts (Corymbia, section Ochraria, Myrtaceae). Biochem Syst Ecol 1998, 26:239-249.

13. Doyle J, Doyle J: A rapid procedure for DNA purification from small quantities of fresh leaf tissue. Phytochem Bull 1987, 19:11-15.

14. Carrier G, Santoni S, Rodier-Goud M, Canaguier A, De Kochko A, Dubreuil-Tranchant C, This P, Boursiquot J-M, Le Cunff L: An efficient and rapid protocol for plant nuclear DNA preparation suitable for next generation sequencing methods. Am J Bot 2011, 98:e13-15

15. Peterson DG, Boehm KS, Stack SM: Isolation of milligram quantities of nuclear DNA from tomato (Lycopersicon esculentum), a plant containing high levels of polyphenolic compounds. Plant Mol Biol Report 1997, 15:148-153.

16. Shepherd M, Cross M, Stokoe RL, Scott LJ, Jones ME: High-throughput DNA extraction from forest trees. Plant Mol Biol Report 2002, 20:425.

17. Furtado A: DNA Extraction from Vegetative Tissue for Next-Generation Sequencing. In Cereal Genomics Methods and Protocols. Edited by Henry RJ, Furtado A, Springer Protocols. 2014:1-5.

18. Furtado A, Henry RJ: The wheat Em promoter drives reporter gene expression in embryo and aleurone tissue of transgenic barley and rice. Plant Biotechnol J 2005, 3:1-14.

19. Couch JA, Fritz PJ: Isolation of DNA from plants high in polyphenolics. Plant Mol Biol Report 1990, 8:8-12.

20. Katterman FRH, Shattuck VI: An effective method of DNA isolation from the mature leaves of Gossypium species that contain large amounts of phenolic terpenoids and tannins. Prep Biochem 1983, 13:347-359.

21. Henry RJ: Plant DNA Extraction. In Plant Genotyping DNA Fingerprinting Plants. Edited by Henry RJ, CAB International. 2001:239-250.

22. Fang G, Hammar S, Grumet R: A quick and inexpensive method for removing polysaccharides from plant genomic DNA. Biotechniques 1992, 13:52-54.

23. Ewing B, Green P: Base-calling of automated sequencer traces using Phred. II. Error probabilities. Genome Res 1998, 8:186-194.

doi:10.1186/1746-4811-10-21

Cite this article as: Healey et al:: Protocol: a simple method for extracting next-generation sequencing quality genomic DNA from recalcitrant plant species. Plant Methods 2014 10:21

\section{Submit your next manuscript to BioMed Central and take full advantage of:}

- Convenient online submission

- Thorough peer review

- No space constraints or color figure charges

- Immediate publication on acceptance

- Inclusion in PubMed, CAS, Scopus and Google Scholar

- Research which is freely available for redistribution 